Article

\title{
Amination of Graphene Oxide Leads to Increased Cytotoxicity in Hepatocellular Carcinoma Cells
}

\author{
Milena Georgieva ${ }^{1}\left(\mathbb{D}\right.$, Bela Vasileva $^{1}$, Giorgio Speranza ${ }^{2}{ }^{(}$, Dayong Wang ${ }^{3}$, Kalin Stoyanov ${ }^{4}(\mathbb{D}$, \\ Milena Draganova-Filipova ${ }^{5,6}$, Plamen Zagorchev ${ }^{7}$, Victoria Sarafian ${ }^{5,6}$, George Miloshev ${ }^{1}$ and \\ Natalia Krasteva ${ }^{8, *}$ (D) \\ 1 Institute of Molecular Biology "Roumen Tsanev", Bulgarian Academy of Sciences, 1113 Sofia, Bulgaria; \\ milenageorgy@gmail.com (M.G.); belavas@outlook.com (B.V.); karamolbiol@gmail.com (G.M.) \\ 2 Functional Materials and Photonic Structure, Center for Materials and Microsystems, Fondazione Bruno \\ Kessler, I-38123 Povo, Italy; speranza@fbk.eu \\ 3 Department of Biochemistry and Molecular Biology, Medical School in Southeast University, Nanjing 210009, \\ China; dayongw@seu.edu.cn \\ 4 Department of Automation, University of Chemical Technology and Metallurgy, 1756 Sofia, Bulgaria; \\ kalin.stoyanov@uctm.edu \\ 5 Department of Medical Biology, Medical Faculty, Medical University_Plovdiv, 4000 Plovdiv, Bulgaria; \\ milena_draganovafilipova@abv.bg (M.D.-F.); sarafian@abv.bg (V.S.) \\ 6 Research Institute at Medical University-Plovdiv, Bulgaria; 15A Vassil Aprilov, blvd, 4000 Plovdiv, Bulgaria \\ 7 Department of Physics and Biophysics, Faculty of Pharmacy, Medical University_Plovdiv, 4000 Plovdiv, \\ Bulgaria; plamenz@gbg.bg \\ 8 Institute of Biophysics and Biomedical Engineering, Bulgarian Academy of Sciences, 1113 Sofia, Bulgaria \\ * Correspondence: nataly@bio21.bas.bg; Tel.: +359-889577074
}

Received: 5 February 2020; Accepted: 29 March 2020; Published: 31 March 2020

\begin{abstract}
Clinically, there is an urgent need to identify new therapeutic strategies for selectively treating cancer cells. One of the directions in this research is the development of biocompatible therapeutics that selectively target cancer cells. Here, we show that novel aminated graphene oxide (haGO-NH${ }_{2}$ ) nanoparticles demonstrate increased toxicity towards human hepatocellular cancer cells compared to pristine graphene oxide(GO). The applied novel strategy for amination leads to a decrease in the size of haGO-NH $\mathrm{N}_{2}$ and their zeta potential, thus, assuring easier penetration through the cell membrane. After characterization of the biological activities of pristine and aminated GO, we have demonstrated strong cytotoxicity of haGO- $\mathrm{NH}_{2}$ toward hepatic cancer cells-HepG2 cell line, in a dose-dependent manner. We have presented evidence that the cytotoxic effects of haGO- $\mathrm{NH}_{2}$ on hepatic cancer cells were due to cell membrane damage, mitochondrial dysfunction and increased reactive oxygen species (ROS) production. Intrinsically, our current study provides new rationale for exploiting aminated graphene oxide as an anticancer therapeutic.
\end{abstract}

Keywords: cytotoxicity; genotoxicity; HepG2; nanoparticle functionalization; GO; hydroxylamine; haGO-NH ${ }_{2}$

\section{Introduction}

Recently, novel therapeutic approaches, based on different nanoparticles, have been identified as a promising multi-modal approach for enhancing therapeutic efficacy and reducing side effects associated with cancer treatment [1-3]. Nanoparticles are associated with a more targeted localization in tumors and cellular uptake on an active mode, making it possible to achieve controlled drug-released delivery and when possible specific gene transfection [4,5]. 
Graphene oxide (GO) nanoparticles are broadly used nowadays due to GO properties and characteristics. GO is a two-dimensional carbon nanomaterial with unique combination of physical and chemical properties, and great potential for use as drug carrier in targeted cancer treatment $[6,7]$. Structurally, GO presents a graphene-like sheet, laced with carboxyl groups on its edge and hydroxyl/epoxy groups on its basal plane [8]. The layered structure has both, a large surface area and abundant oxygen-containing groups facilitating functionalization of $\mathrm{GO}$ with bioactive molecules to increase loading of hydrophobic or aromatic anticancer drugs and to ease cancer-cell targeting. Cancer-cell targeting antibodies and molecules, such as DNA, peptides, polymers, etc. are easily adsorbed onto the GO surface through non-covalent $\pi-\pi$ interactions or electrostatic interactions, while the organic molecules, including drugs, are able to covalently conjugate with GO [9]. Additionally, the GO nanosheets, produced by the modified Hummer's method, demonstrate stability in water suspensions and high biocompatibility [10], mainly because of the presence of hydrophilic oxygenated groups, which makes them ideal materials for application in drug delivery [11].

The toxicity of GO has been focused recently, but there is currently a lack of consistency in this regard. According to some authors, GO has a minor effect on the viability and morphology of different cancer cells [11,12], while others have proven that GO may generate oxidative stress, causing adverse effects on the viability of HaCaT (non-tumor skin keratinocytes) and liver cancer cells [13,14]. Moreover, GO treatment could lead to structural deformation of mitochondria, thus, affecting the mitochondrial membrane potential [15]. Many studies prove that the cellular toxicity of GO in vitro is closely related to its surface functionalization [16]. The latter provokes alterations in the physicochemical properties of GO, which impacts its application in cancer therapy. Exposure to $\mathrm{COOH}$-functionalized GO nanoparticles, for example, can cause passive apoptosis in T-lymphocytes, while PEG-modified GOs cause severe hemotoxicity in the same cells by inducing membrane damage [17]. PEGylation reduces the non-specific binding of GO to biological membranes and improves its in vivo pharmacokinetics for better tumor targeting $[18,19]$. In our previous study, we found that exposure to ammonia-modified GO NPs could induce cell cycle arrest in the G2/M phase, thus, significantly increasing the apoptosis rate and the generation of reactive oxygen species (ROS) in colorectal Colon 26 and lung A549 cancer cells, but did not influence the viability of non-tumor embryonic stem cells [20,21]. Our findings highlight the potential of GOs NPs to be used as anticancer drugs. The data prove that functionalization of GO can be used to modulate GO cytotoxicity and genotoxicity, and to design effective strategies for cancer therapy. Importantly, the better we understand the physiochemical properties of NPs, their interactions with the cells and the possible toxicity mechanisms, the more precisely their potential biomedical applications could be outlined. Therefore, further studies are warranted to fully understand the cellular toxicological mechanism of functionalized GO NPs.

In view of the insignificant knowledge about the mechanisms of toxicity of aminated GO NPs, this study was designed to investigate the biological mechanisms of cytotoxicity of newly synthesized and functionalized GO NPs on human hepatocellular carcinoma (HepG2) cells. Hepatocellular carcinoma (HCC) is an aggressive tumor typically occurring in patients with chronic liver disease [22]. It is the second leading cause of cancer death in East Asia and sub-Saharan Africa and the sixth most common in Western countries [23,24]. The prevalence of HCC is increasing due to the increasing incidence of hepatitis infection, obesity, and metabolic syndrome, as well as increased survival of patients with liver disease [25]. Actually, the HCC is one of the biggest challenges in cancer treatment, due to its different molecular pathways, causing agents, and late diagnosis. Depending on the disease stage, there are several treatments, such as surgical resection, ablation, transplantation, chemoembolization, and medication with Sorafenib [26-28]. However, all treatments bring side effects that impair the quality of patients' life. In addition, the high toxicity and relative non-specificity of conventional anticancer drugs, used for the treatment of HCC, impede long-term application [29].

We have developed an easy, one-step protocol for amination of GO by hydroxylamine, which is much simpler than the commonly used protocols for amination of GO by ammonia. We aimed to study the potential cytotoxicity of pristine and hydroxylamine aminated $\mathrm{GO}\left(\right.$ haGO- $\mathrm{NH}_{2}$ ) on 
HepG2 cells, focusingon the assessment of the rate of ROS production and mitochondrial dysfunction. Our results showed that hydroxylamine aminated GO induced cytotoxicity, oxidative stress, membrane leakage and mitochondrial dysfunction in HepG2 cells while DNA damage was insignificant. To the best of our knowledge, these data are the first that link aminated GO with potential impairment of the mitochondrial metabolism and will be of profound clinical significance for the development of aminated GO NPs, either as stand-alone therapeutics, or in combination with other anticancer drugs.

\section{Results}

\subsection{Structural and Biophysical Characterization of $\mathrm{GO}$ and haGO-NH $\mathrm{H}_{2}$ Nanoparticles}

Graphene oxide nanoparticles, pristine and aminated by hydroxylamine were characterized structurally and biophysically by subsequently evaluating their chemical composition, morphology, size, hydrodynamic diameter and zeta potential. X-ray photoemission spectroscopy (XPS) was utilized to estimate the amination of GO upon modification of GO with hydroxylamine. XPS allows specific characterization of GO materials through both, atomic survey scans and high-resolution atomic scans. Peak fitting of high resolution XPS is a powerful and commonly used tool for detection of specific chemical modifications of different materials. Deconvolution of high resolution N1s XPS provided evidence that the nitrogen is covalently attached to GO in the haGO-NH${ }_{2} \mathrm{NPs}$. The N1s fit components were assigned to $\mathrm{C}=\mathrm{N}$ and amine bonds $(398.4 \mathrm{eV})$, amide or imide bonds $(399.89 \mathrm{eV})$ and protonated amines $(401.6 \mathrm{eV})$. XPS survey scans proved that haGO- $\mathrm{NH}_{2}$ contains amino groups because haGO-NH $\mathrm{N}_{2}$ amine peak was absent in pristine GO and the peak at higher BE is much more pronounced (Figure 1). Additionally, the high-resolution XPS C1s and O1s spectra demonstrated an alteration in the percentage of bonds in GO and haGO-NH${ }_{2}$ NPs suggesting that amination affected the functional groups in GO. For example, the percentage of $\mathrm{C}-\mathrm{O}(532.65 \mathrm{eV})$ in haGO- $\mathrm{NH}_{2}$ decreased with $17.3 \%$, while the percentage of $\mathrm{C}=\mathrm{O}(531.49 \mathrm{eV})$ increased with $18.62 \%$ when compared to GO. Also, a peak at 1022.9 was registered in $\mathrm{GO}-\mathrm{NH}_{2}$ NPs corresponding to the $\mathrm{ZnO}_{2}$ pointing contamination of the sample.
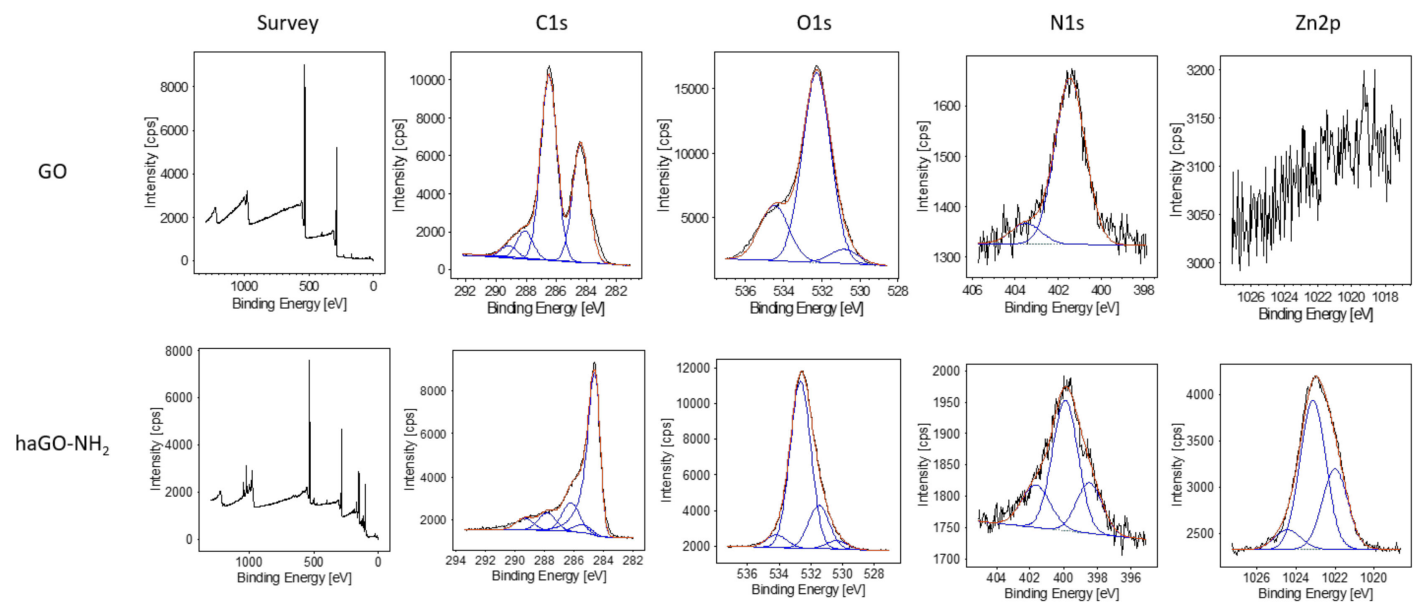

Figure 1. X-ray Photoemission Spectroscopy.The elemental composition of the nanoparticles was analyzed by X-ray photoemission spectroscopy (XPS) on Axis DLD Ultra instrument (Kratos-Manchester, UK).

Transmission electron microscopy (TEM) was used to observe the general morphology of the GOs NPs. The micrographs of pristine and aminated GO NPs (Figure 2A) revealed a two-dimensional sheet-like structure, consisting of one or several layers. The transparency of GO sheets suggested the formation only of few layers. The GO sheets had an irregular, wrinkled shape with sharp edges. Compared with pristine GO, haGO- $\mathrm{NH}_{2}$ sheets were more wrinkled (the right micrograph at Figure $2 \mathrm{~A}$ ) with no other morphological changes being detected. Similar morphologies for both, pristine and aminated by ammonia GO sheets have been observed in our previous studies [21], indicating that the 
different methods of amination of GO resulted in a similar effect on GO morphology, namely increasing the level of crumpling of the modified GO sheets.

A
GO

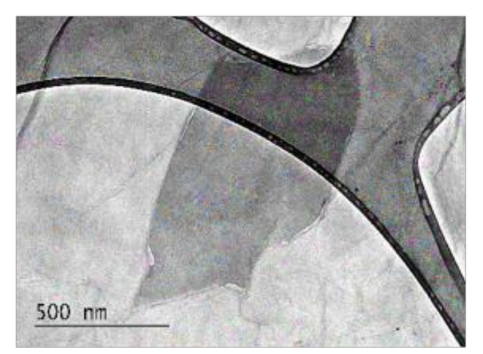

haGO-NH $\mathrm{NH}_{2}$

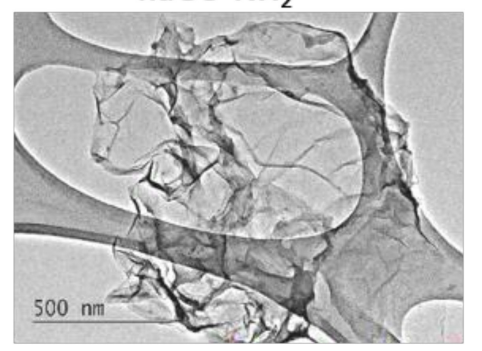

B

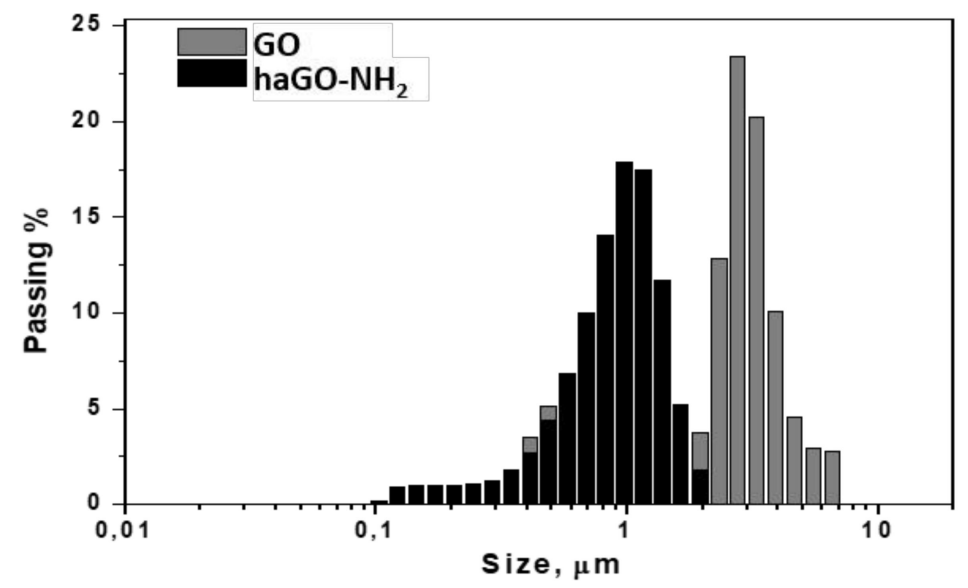

C

\begin{tabular}{l|l|l} 
Samples & GO & haGO- $\mathrm{NH}_{2}$ \\
\hline Zeta Potential & $-33.7 \mathrm{mv} \pm 0.4$ & $-12.28 \mathrm{mv} \pm 0.6$ \\
\hline Polarity & Negative & Negative \\
\hline Conductivity & $157 \mathrm{uS} / \mathrm{cm}$ & $148 \mathrm{uS} / \mathrm{cm}$
\end{tabular}

Figure 2. Biophysical characterization of GO and haGO- $\mathrm{NH}_{2}$ nanoparticles. (A) TEM micrographs of $\mathrm{GO}$ and haGO-NH $\mathrm{H}_{2}$. Images were acquired at $200 \mathrm{kV}$ using Holey-carbon film on 300 mesh nickel grids. $(\mathbf{B}, \mathbf{C})$ Characterization of size and zeta potential of the nanoparticles in solution, were performed on a Zetatrac instrument (S3500; Microtrac, Largo, FL).

Dynamic light scattering (DLS) is a particularly important technique for determining nanoparticle size and size distribution in aqueous suspensions. We have implemented DLS measurements in aqueous solutions to elucidate the size of the studied GO and haGO- $\mathrm{NH}_{2} \mathrm{NPs}$ (Figure 2B). Samples were dispersed in water (at $1 \mathrm{mg} / \mathrm{mL}$ ), followed by sonication for $60 \mathrm{~min}$ and then analyzed with Zetasizer. The pristine GO was found to have very wide size distribution ranging from $280 \mathrm{~nm}$ to $6.4 \mu \mathrm{m}$ (Figure 2B) divided in two fractions: a small fraction of $19.24 \%$ that encompasses the particles ranging from $289 \mathrm{~nm}$ to $818 \mathrm{~nm}$ in size with average particle size of $515 \mathrm{~nm}$ and a main fraction of $80.76 \%$ with particles in the range of $1.64 \mu \mathrm{m}$ to $6.54 \mu \mathrm{m}$ with average particle size of $3.6 \mu \mathrm{m}$. Aminated GO NPs were more homogeneous and smaller in size ranging from $102 \mathrm{~nm}$ to $1.944 \mu \mathrm{m}$ with average particle size of $594 \mathrm{~nm}$.

The zeta potential ( $\zeta$-potential) of GO and haGO-NH${ }_{2} \mathrm{NPs}$ was measured in order the colloidal stabilities of nanoparticles to be determined. Many data show that a colloidal dispersion is stable when a force causes the mutual repulsion of the particles [30]. In general, a particle suspension with a zeta potential of around $-30 \mathrm{mV}$ is considered as a stable dispersion [31]. The table on Figure 2C contains 
zeta potential values for both types of pristine and aminated GO samples at room temperature. The zeta potential values for pristine $\mathrm{GO}$ samples were $-33.7 \mathrm{mV}$ when dispersed in water and increased to $-12.28 \mathrm{mV}$ after amination. Pristine GO suspension demonstrated higher colloidal stability than aminated GO. Taken together, the results from Zetasizer measurements suggested that amination by hydroxylamine decreased the size of haGO- $\mathrm{NH}_{2} \mathrm{NPs}$ and their zeta potential, suggesting easier penetration of the nanoparticles through the cell membrane.

\subsection{Cytotoxicity of Hydroxylamine Modified GO (haGO-NH $\mathrm{H}_{2}$ ) Nanoparticles Is Increased in HepG2 Cells While Cell Morphology Remains Unchanged}

The biological effects of GO nanoparticles, pristine and hydroxylamine aminated, were tested on HepG2 cells. Cytotoxicity was measured after $24 \mathrm{~h}$ exposure of the cells to different concentrations of the two types of NPs. The tested concentrations were 4, 10, 25 and $50 \mu \mathrm{g} / \mathrm{mL}$ f.c. The optical density (OD) of cells treated with GO and haGO- $\mathrm{NH}_{2}$ was spectrophotometrically measured at $450 \mathrm{~nm}$ wavelength (Figure 3). To illustrate the trend by which both types of GO NPs exert their cytotoxic activity on HepG2 cells we have built linear regression models (Figure 3A,B). The green dots represent the measured values. The R squared statistics were also included. The trend towards increasing the concentrations of the GO and the measured cytotoxicity is obvious (Figure 3A), but the observed effect of the exposure to GO was not strong. Moreover, considering the measuring error (notice the rather wide variation), one can conclude that the effect of GO is almost negligible. The level denoted by " $\mathrm{K}$ " marks the values without GO. Our results showed that the pristine GO NPs reduced cell viability only after treatment with higher concentrations of 25 and $50 \mu \mathrm{g} / \mathrm{mL}$, while the lower concentrations of 4 and $10 \mu \mathrm{g} / \mathrm{mL}$ had slight stimulating effect on cells, assumed as the so-called hormesis effect.
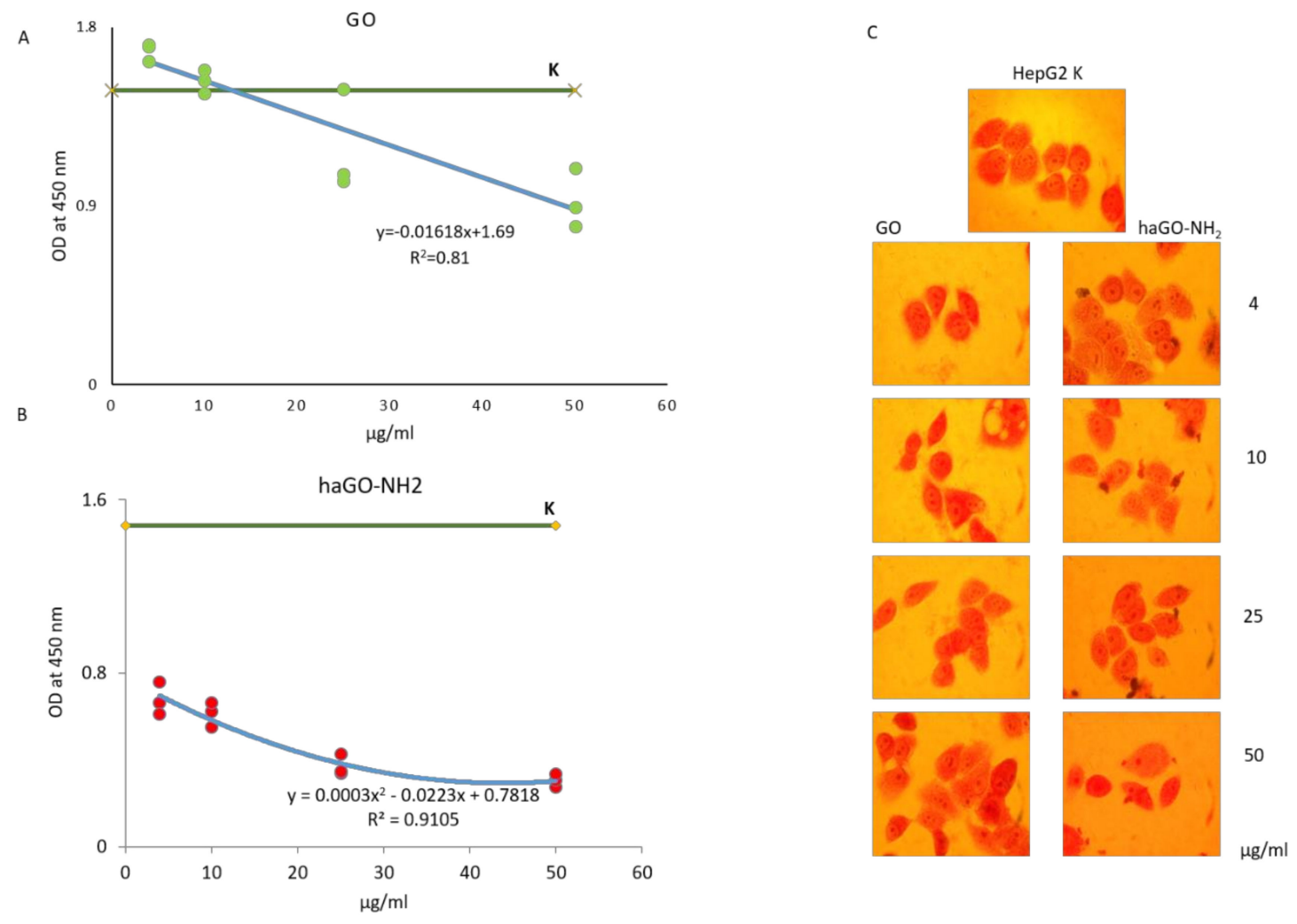

Figure 3. Cell viability and morphology of HepG2 cells treated for $24 \mathrm{~h}$ with $\mathrm{GO}$ and haGO-NH 2 . (A,B) WST-8 (Sigma-Aldrich Co.) was used to evaluate cell viability - linear regression models for both types of GO NPs cytotoxic effect on HepG2 cells. (C) A panel of micrographs with neutral red stained HepG2 cells taken under phase contrast microscopy after $24 \mathrm{~h}$ of incubation of the cells with different concentrations of GO and haGO- $\mathrm{NH}_{2}$. Magnification $25 \times$. 
Figure 3B demonstrates the linear regression model for the effect of the hydroxylamine modified haGO- $\mathrm{NH}_{2}$. It is easily observed that, even with the lowest concentration $(4 \mu \mathrm{g} / \mathrm{mL})$ of the aminated $\mathrm{NPs}$, the OD has decreased significantly down to 0.7 with variation between 0.61 and 0.76 and gradually decreased until 0.30, comparing the levels of " $\mathrm{K}$ " at zero concentration of haGO- $\mathrm{NH}_{2}$ (1.48). Also one can see that the trend is not linear but quadratic - the regression model has correlation coefficient 0.91 (Figure 3B), which demonstrates much better fit than the linear model over the same data from the previous example. This model also prompts saturation of the effect of haGO-NH $\mathrm{N}_{2}$ at a concentration of $50 \mu \mathrm{g} / \mathrm{mL}$. Observation of neutral red labeled hepatocytes did not show any significant alterations in cell morphology (Figure 3C).

Cytotoxicity was additionally assessed by measurement of the leakage of lactate dehydrogenase (LDH). LDH is an enzyme, which is released into the surrounding extracellular space following cell exposure to cytotoxic compounds. When the cell membrane integrity is compromised, the detection of LDH in the culture medium can be used as a cell-death marker [32]. To evaluate the levels of LDH leakage after incubation with both types of GO NPs, HepG2 cells were treated with GO and haGO-NH for $24 \mathrm{~h}$, followed by measurement of LDH levels (Figure 4). Cells with a fully compromised cell membrane were obtained after treatment with Triton X-100. The LDH release values were quantified as a percentage of the LDH release in Triton X-100 treated cells which was taken as $100 \%$. The obtained results showed that HepG2 cells exposed to 4, 10 and $25 \mu \mathrm{g} / \mathrm{mL}$ GO NPs displayed similar levels of $\mathrm{LDH}$ release compared to the untreated cells during the whole cultivation period (Figure 4A).
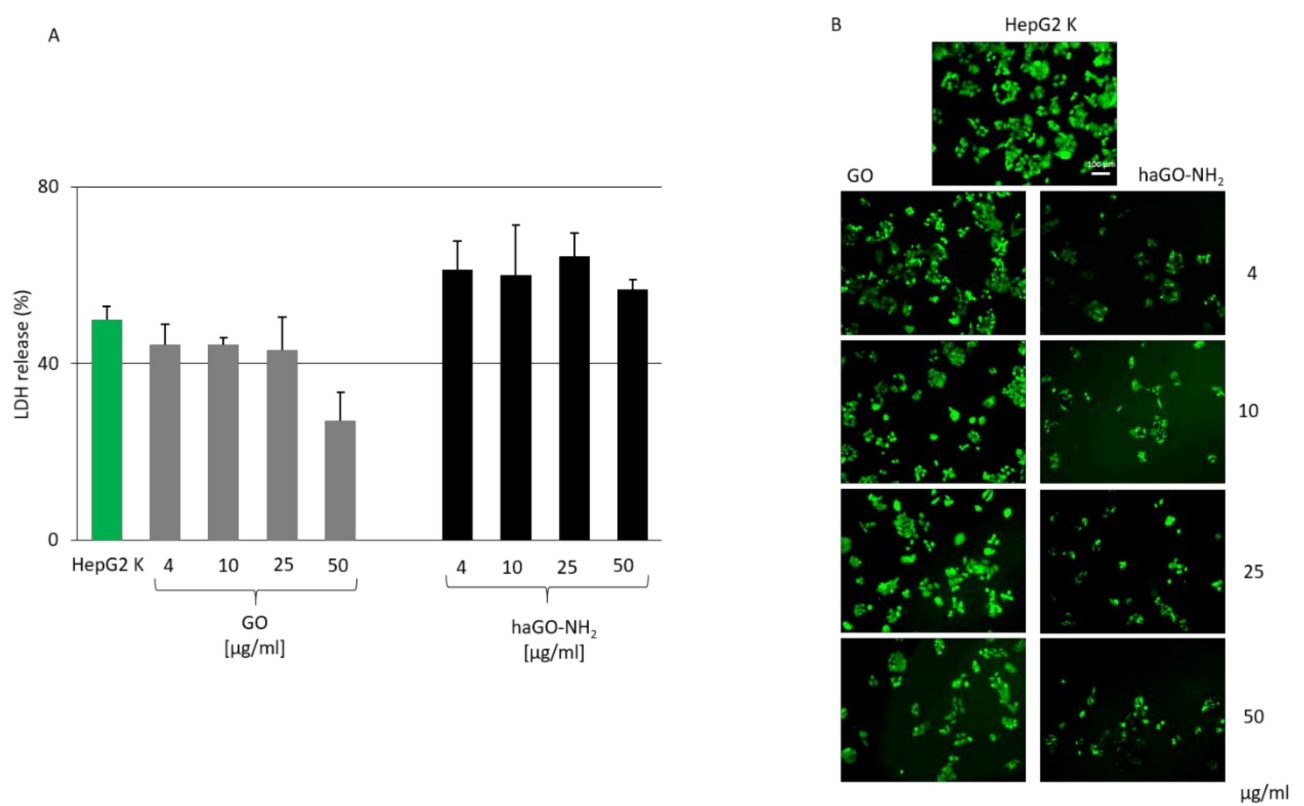

Figure 4. Membrane integrity of HepG2 cells treated for $24 \mathrm{~h}$ with pristine and aminated GO. (A) Percentage of LDH release fromHepG2 cells after $24 \mathrm{~h}$ of incubation in the presenceof different concentrations of GO and haGO-NH $\mathrm{N}_{2}$ nanoparticles. Cells treated with Triton X-100 were used as a positive control. The LDH release values were quantified as a percentage of the LDH release in Triton X-100 treated cells which was taken as 100\%. Values are MEAN \pm STDV from three repetitive experiments. (B) A panel of FDA-stained HepG2 cells taken under a fluorescent microscope after the cells were treated with increasing concentrations of GO and haGO- $\mathrm{NH}_{2}$ nanoparticles for $24 \mathrm{~h}$. Magnification 10×; bar $100 \mu \mathrm{m}$.

A statistically significant increase in LDH release $(p<0.001)$ was noticed after $24 \mathrm{~h}$ of exposure of HepG2 cells to haGO-NH $\mathrm{N}_{2}$ NPs which however was not found to be concentration-dependent. Interestingly, we have found a decrease in LDH levels in GO-treated cells with concentration of $50 \mu \mathrm{g} / \mathrm{mL}$. Analysis of LDH leakage revealed that only aminated GO NPs affect cell membrane integrity, which possibly induce cytotoxicity in HepG2 cells. 
Cell membrane integrity after $24 \mathrm{~h}$ exposure to GO and haGO-NH $\mathrm{N}_{2} \mathrm{NPs}$ was qualified by FDA staining. FDA is a non-polar and non-fluorescent molecule, which enters the cell. Inside, it is hydrolyzed by intracellular cell esterases, and fluorescein is produced. This polar compound cannot leave the viable cell because it is unable to pass through the intact cell membrane, and accumulates in the cytoplasm of the cell and exhibits green fluorescence. Damaged cells, however, cannot retain the fluorescein, and they fluoresce very poor or are unstained. Fluorescent images on Figure 4B clearly show that the number of viable cells is reduced in haGO- $\mathrm{NH}_{2}$ treated samples suggesting the haGO- $\mathrm{NH}_{2}$ compromised in a greater degree the cell membrane than GO, which results in cell detachment and death.

\subsection{Elevated Oxidative Stress in HepG2 Cells Detected after Incubation with haGO-NH $\mathrm{H}_{2}$}

Another possible mechanism for induction of cytotoxicity in HepG2 cells after incubation with the tested nanoparticles could be the elevated production of reactive oxygen species (ROS) leading to increased oxidative stress. ROS are by-products of biochemical reactions like mitochondrial respiration and cytochrome P450 enzymatic metabolism which have the potential to cause oxidative stress and damage in bio-molecules like lipids, proteins and DNA when ROS levels increase. Nanoparticles are known to initiate oxidative stress directly or indirectly through various mechanisms, thus exerting negative biological effects [33]. To verify the effects of tested GO NPs on oxidative stress, HepG2 cells were treated with both types of GO NPs for $24 \mathrm{~h}$ and ROS levels were then measured using enzymatic cleavage of DCFH-DA. As shown in Figure 5, HepG2 cells treated with both types of GOs NPs demonstrated a dose-dependent increase in ROS production. However, only the highest concentration of pristine GO $(50 \mu \mathrm{g} / \mathrm{mL})$ induced higher ROS production than the control cells. Inversely, all tested concentrations of haGO-NH $\mathrm{N}_{2}$ induced production of much higher ROS levels than those measured in non-treated cells and in $\mathrm{GO}$ treated cells. This indicated that haGO- $\mathrm{NH}_{2}$ may potentially cause oxidative stress, which could impair normal physiological redox-regulated functions and thus induce cell death as detected in the previous experiments measuring cytotoxicity.

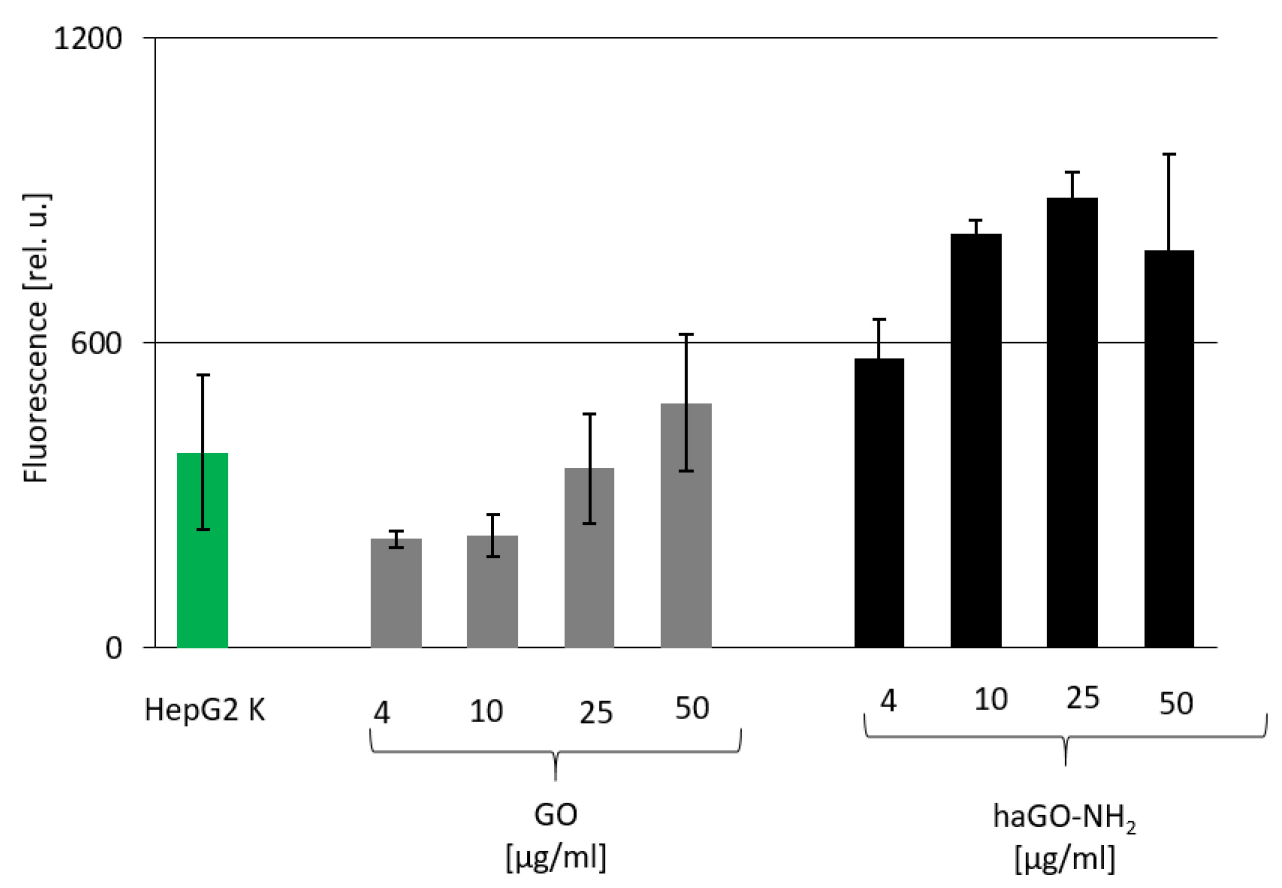

Figure 5. ROS production in HepG2 cells after treatment with GO nanoparticles. The production of intracellular ROS was measured using 2,7-dichlorofluorescin diacetate. HepG2 cells were seeded in 24-well plates and allowed for adherence. The fluorescence intensity of DCF was detected on a spectrofluorometer upon excitation at $485 \mathrm{~nm}$ and emission at $520 \mathrm{~nm}$. 


\subsection{Both Types of Graphene Oxide Nanoparticles (GO and haGO-NH$H_{2}$ ) Trigger Mitochondrial Dysfunction in HepG2 Cells}

One major source of increased cellular ROS levels is dysfunctional mitochondria. The mitochondrial oxygen consumption rate (OCR), which is a key metric of aerobic mitochondrial function, and the extracellular acidification rate (ECAR), which approximates glycolytic activity, were analyzed simultaneously using a standard mitochondrial stress test paradigm on a Seahorse analyser. The Seahorse analyzer permits to measure oxidative phosphorylation in a more physiologically relevant context. We estimated OCR and ECAR in HepG2 cells, treated with pristine and aminated graphene oxide NPs, for $24 \mathrm{~h}$. Initially, we measured the basal respiration, and then, respiration after sequential injection of oligomycin, FCCP and antimycin. Oligomycin blocks ATP synthase activity and enables mitochondrial ATP production to be evaluated. FCCP is a powerful OxPhos uncoupler, which uncouples ATP synthesis from the ETC to dissipate the mitochondrial membrane potential and assess maximal mitochondrial activity independently of ATP production. Antimycin blocks residual mitochondrial activity to account for non-mitochondrial oxygen consumption. Measuring the change in concentrations of oxygen $\left(\mathrm{O}_{2}\right)$ and free proton $\left(\mathrm{H}^{+}\right)$, in the extracellular media over a prescribed time frame, provides data about the oxygen consumption rate $(\mathrm{OCR}, \mathrm{pmol} / \mathrm{min})$ and extracellular acidification rate (ECAR pmol/min). As shown in Figure 6A, the mitochondrial respiration of HepG2 cells was compromised by both types of GO NPs. The toxic effects of GO and haGO-NH $\mathrm{NH}_{2}$ on HepG2 cells resulted in a decreased basal OCR, ATP-linked respiration, proton leakage and maximal respiration in comparison to the non-treated controls. Both types of GO NPs demonstrated a dose-dependent effect on basal OCR, ATP-linked respiration and proton leakage. However, our results show that they influenced the components of OCR differently and the effect of haGO- $\mathrm{NH}_{2}$ on mitochondrial functions was stronger compared to pristine GO NPs. GO and haGO- $\mathrm{NH}_{2}$ NPs decreased mitochondrial respiration of HepG2 cells even at the basal state (Figure 6B). Treatment of HepG2 cells with 4 and $10 \mu \mathrm{g} / \mathrm{mL}$ of $\mathrm{GO}$ and haGO- $\mathrm{NH}_{2}$ had small effect on basal respiration, while the highest concentrations of 25 and 50 $\mu \mathrm{g} / \mathrm{mL}$ reduced basal respiration significantly compared to the control samples. In general, the basal OCR is composed of respiration linked to ATP production and proton leakage. ATP-linked respiration (Basal OCR - Oligomycin response) was significantly lower $(p<0.05)$ in both, 25 and $50 \mu \mathrm{g} / \mathrm{mL} \mathrm{GO}$ and haGO-NH ${ }_{2}$ treated groups: 30 and $17.85 \mathrm{pmol} / \mathrm{min}$ as well as 29 and $25 \mathrm{pmol} / \mathrm{min}$ versus both controls 57.75 and $49 \mathrm{pmol} / \mathrm{min}$. Proton leak (Antimycin A and Rotenone response - Oligomycin response) was reduced in a greater degree in $50 \mu \mathrm{g} / \mathrm{mL}$ GO and haGO- $\mathrm{NH}_{2}$ treated samples: 15 , and $20 \mathrm{pmol} / \mathrm{mL}$, respectively versus 28 and $31 \mathrm{pmol} / \mathrm{mL}$ for the controls, in a lower degree in 4,10 and $25 \mu \mathrm{g} / \mathrm{mL}$ haGO-NH${ }_{2}$-treated samples. However, in $4 \mu \mathrm{g} / \mathrm{mL}$ GO-treated cells, it was similar to the normal level (31 versus $28 \mathrm{pmol} / \mathrm{min}$ ). Changes in the proton leak pathway affect respiration rate - the increased proton leak uncouples oxidation and phosphorylation, i.e., decreases coupling efficiency. We found that the coupling efficiency decreases in both cases - after GO (from 68 to $54 \%$ ) and after haGO-NH ${ }_{2}$ treatment (from 73 to 61\%) (Figure 6B). This uncoupling very possibly reduced ATP production.

The maximal respiratory capacity was estimated by an FCCP-stimulated respiration and the observed decrease was a strong indicator of potential mitochondrial dysfunction. The experiments, conducted with both GO types, indicated that GO and haGO- $\mathrm{NH}_{2}$ caused perturbations in mitochondrial respiration. In GO-treated cells, the maximum respiration decreased in a dose-dependent manner, while in HepG2 cells-treated with 4, 25 and $50 \mu \mathrm{g} / \mathrm{mL}$ haGO- $\mathrm{NH}_{2}$ had a similar effect. However, in cells treated with $10 \mu \mathrm{g} / \mathrm{mL}$ haGO-NH${ }_{2}$, an even weaker stimulating effect was observed. The cell spare respiratory capacity (SRC), however, was not impaired after 24 h-treatment with GO and haGO-NH ${ }_{2}$ NPs. The mitochondrial SRC is regarded as an important aspect of the mitochondrial function and is calculated by the difference between maximal and basal cellular OCR. When cells are subjected to stress, energy demands increase, with more ATP required to maintain cellular functions. A cell with a larger spare respiratory capacity can produce more ATP and overcome stress more effectively, which indicates that this could estimate the cells' ability to cope with large increases in ATP turnover [34]. Consequently, GOs exposure, which negatively affects mitochondrial function, 
possibly exerts negative effects on the ability of cells to cope with other stress. Finally, the addition of a potent respiratory chain inhibitor, such as antimycin A, allows the estimation of non-mitochondrial OCR. In GO-treated samples, non-mitochondrial oxygen consumption decreased with increasing of GO concentrations, but without statistical significance. While, the effect in haGO- $\mathrm{NH}_{2}$ treated cells was exactly the opposite. There was a slight increase in this parameter with the increase of NPs concentrations, statistically significant only in cells treated with the highest concentrations of $50 \mu \mathrm{g} / \mathrm{mL}$ haGO-NH 2 (Figure 6B).

A
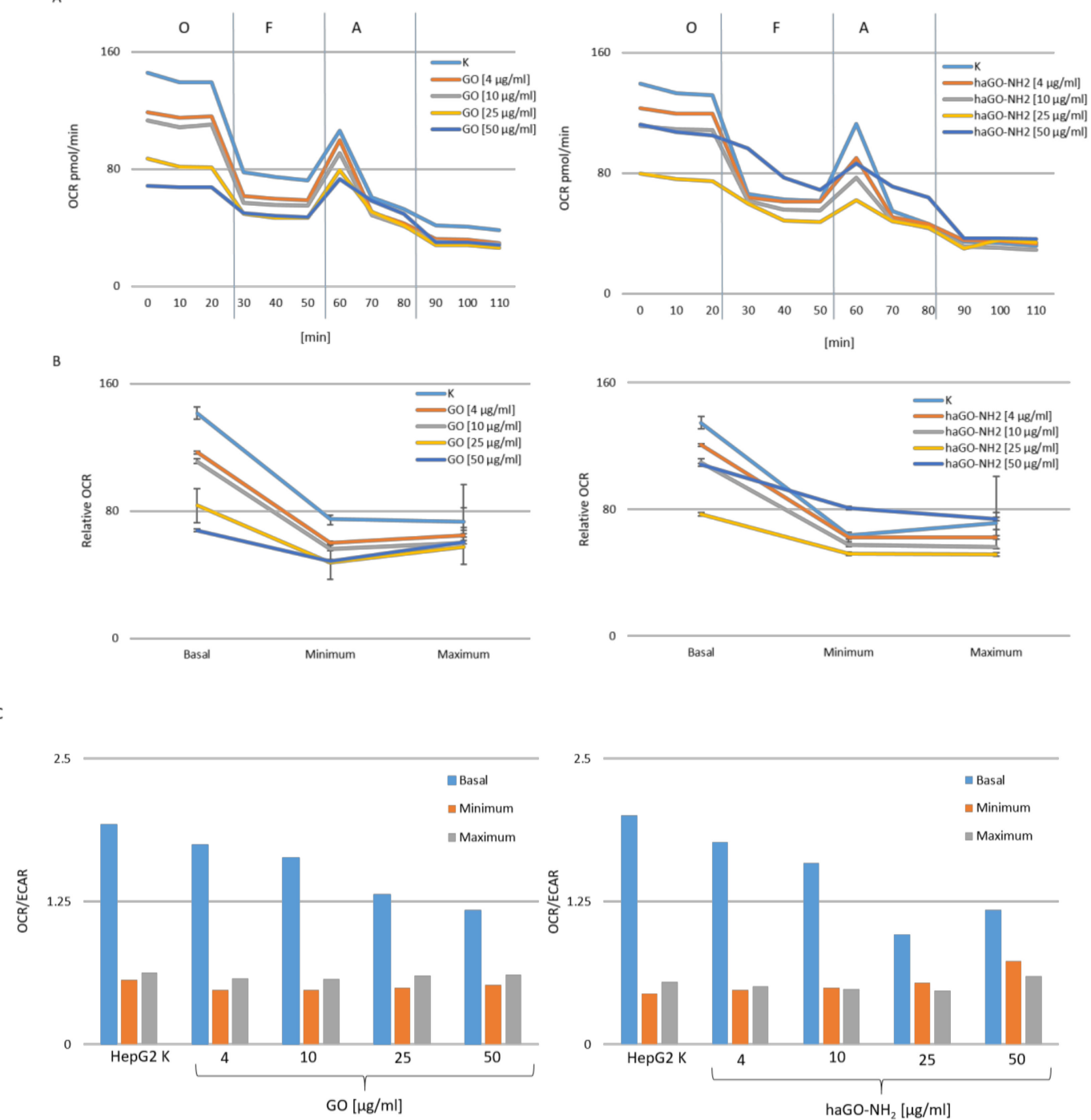
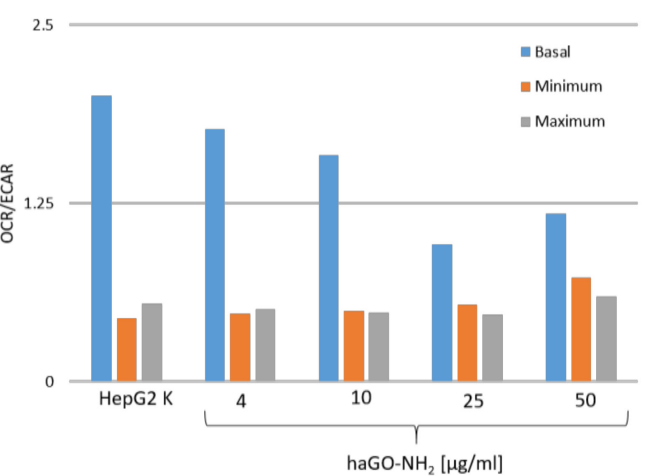

Figure 6. Metabolic studies of HepG2 cells treated with GO and haGO-NH $\mathrm{N}_{2}$ NPs by Seahorse analyses. (A) Mitochondrial oxygen consumption rate (OCR) of HepG2 cells treated with pristine and aminated GO NPs for $24 \mathrm{~h}$ in real time under basal conditions and in response to mitochondrial inhibitors $(\mathrm{O}$, oligomycin; F, FCCP; A, antimycin). (B) Mitochondrial parameters of cells treated for $24 \mathrm{~h}$ with GO and haGO-NH $\mathrm{N}_{2}$. (C) Representation of the ratio between the basal OCR and ECAR where the OCR was measured at the same time as ECAR for HepG2 cells after treatment with both types of NPs.

Additionally, we have used the extracellular acidification rate (ECAR) as a proxy to evaluate glycolytic activity. We have calculated the rate between OCR and ECAR and have found that cells treated with both types of NPs had a lower basal OCR to ECAR ratio than the control cells (Figure 6C), suggesting that they rely on glycolysis rather than on OxPhos for ATP production. 


\subsection{Pristine and Aminated GO (GO and haGO-NH $\mathrm{H}_{2}$ ) Prove Non-Genotoxic for HepG2 Cells}

In order to dissect the mechanism of cytotoxicity of the tested pristine and aminated graphene oxide NPs on HepG2 cells we have performed Comet Assay, also called single-cell gel electrophoresis (SCGE). The Comet Assay sensitively detects damages in DNA [35-37]. HepG2 cells were treated with increasing concentrations of GO and haGO-NH $\mathrm{NH}_{2}(4,10,25$ and $50 \mu \mathrm{g} / \mathrm{mL})$ for $24 \mathrm{~h}$ at optimal conditions and were subjected to Comet Assay. HepG2 cells treated with $5 \mathrm{mM} \mathrm{H}_{2} \mathrm{O}_{2}$ for $30 \mathrm{~min}$ at $37^{\circ} \mathrm{C}$ were used as a positive control for genotoxicity. Genotoxicity was further quantified by the software program CometScore and results are shown on Figure 7. "Comet Length" is a parameter in SCGE data analysis that gives representative and precise estimation of the level of genotoxicity of the tested substances. HepG2 cells treated with pristine GO showed very faint almost insignificant presence of DNA damage when incubated for $24 \mathrm{~h}$. On the contrary, the haGO- $\mathrm{NH}_{2}$ displayed slightly higher genotoxicity effect on the cells but surprisingly this was detected at the lowest used concentration of 4 and $10 \mu \mathrm{g} / \mathrm{mL}$. The given trendline (red dotted line on Figure 7) represents the moving average values for Comet length measured for all probes, including the positive control for genotoxicity - HepG2 cells treated with $5 \mathrm{mM} \mathrm{H}_{2} \mathrm{O}_{2}$. It displays the presence of very faint genotoxic potential of $\mathrm{GO}$ and haGO- $\mathrm{NH}_{2}$ on $\mathrm{HepG} 2$ cells, pointing out the mechanisms by which graphene oxide GO NPs exert their biological activities are not centered on the stability and maintenance of genome integrity.

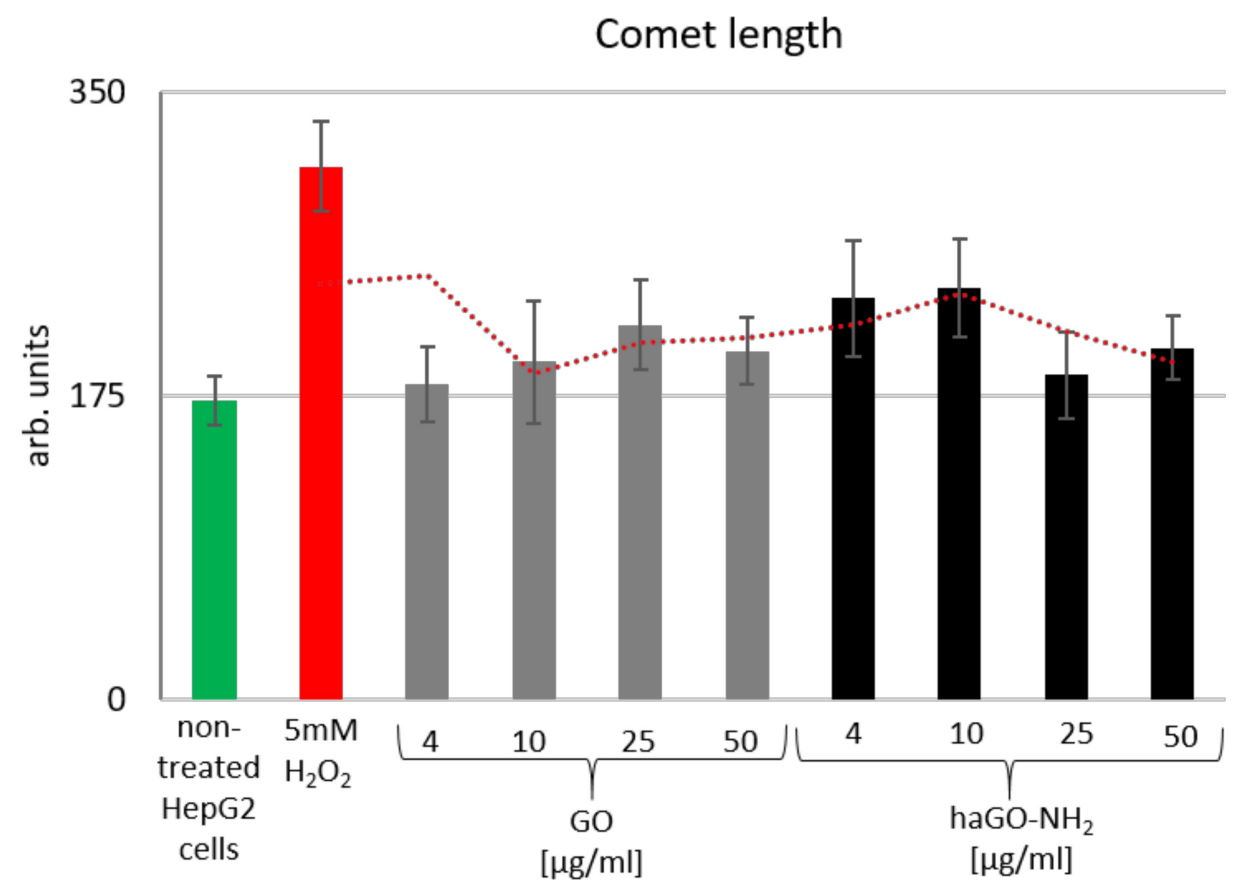

Figure 7. SCGE for testing the genotoxicity potential of pristine and aminated GO nanoparticles on HepG2 cells. Graphical representation of the parameter "Comet length" as quantified by the software CometScore. Data are represented as MEAN \pm STDV, where $n=100$. Additionally, the given trend represents the moving average values for Comet length measured for all probes including the positive control for genotoxicity - HepG2 cells treated with $5 \mathrm{mM} \mathrm{H}_{2} \mathrm{O}_{2}$.

\section{Discussion}

In this work, we studied the efficacy of newly synthesized aminated (haGO- $\mathrm{NH}_{2}$ ) and pristine graphene oxide nanoparticles as potential new anticancer agents for treating hepatocellular carcinoma cells. We developed a new protocol for amination of GO with hydroxylamine, which proved to be simple, cost and time-effective, and moreover, quite successful, as proven by the physico-chemical characterization of the new materials. In our previous research, we investigated commercially available aminated by ammonia graphene oxide nanoparticles $\left(\mathrm{GO}-\mathrm{NH}_{2}\right)$ as anticancer agents for colorectal 
cancer cells. We found that GO-NH $\mathrm{N}_{2}$ NPs trigger stronger cytotoxic and genotoxic effect than pristine GO by induction of ROS, DNA damage and apoptosis in Colon 26 cells [20]. In order to continue with the analysis of the biological effects of aminated GO nanoparticles on other cell types, and to investigate, in detail, the mechanism of nanoparticle action, we developed a new protocol for the synthesis of GO- $\mathrm{NH}_{2} \mathrm{NPs}$ using hydroxylamine as a new reducing agent. The physicochemical characterization of the newly-synthesized hydroxylamine modified haGO-NH${ }_{2} \mathrm{NPs}$ demonstrated that amination by hydroxylamine has a similar modification effect as ammonia on the size and morphology of GO NPs. Both methods of amination led to increased wrinkling of the nanosheets and decreased size of the particles. We have summarized data from physico-chemical characterization together with the biological activity of aminated GO NPs, by both methods in the table below (Table 1). As demonstrated in the table, both aminated types of NPs had very similar size of $560 \mathrm{~nm}$ for GO- $\mathrm{NH}_{2}$ versus $594 \mathrm{~nm}$ for haGO-NH $\mathrm{N}_{2}$. However, a difference in respect to the measured zeta potential between both types of aminated GO NPs was observed. The aminated by hydroxylamine haGO- $\mathrm{NH}_{2}$ had a negative charge $(-12.28 \mathrm{eV})$, while the commercially available $\mathrm{GO}-\mathrm{NH}_{2}$ had a positive charge of at $38.5 \mathrm{eV}$. We suggest that this difference could be referred to as the difference in the total amount of nitrogen in both samples, i.e. $1.86 \%$ in hydroxylamine-aminated haGO- $\mathrm{NH}_{2}$ versus $3.47 \%$ in ammonia-modified GO-NH $\mathrm{NH}_{2} \mathrm{NPs}$ and could result in different interactions with cells. When compared the biological activity of haGO-NH${ }_{2}$ and ammonia-modified GO-NH${ }_{2}$ we have established a reduced cell adhesion ability after exposure to $50 \mu \mathrm{g} / \mathrm{mL}$ NPs, similar in both studied cell types - $21 \%$ in HepG2 cells and $22.5 \%$ in Colon 26 cells. The effect of haGO- $\mathrm{NH}_{2}$ nanoparticles on cell adhesion was stronger than that of ammonia-modified GO-NH $\mathrm{N}_{2} \mathrm{NPs}$ when compared to GO, because in haGO-NH $\mathrm{N}_{2}$-treated HepG2 cells adhesion was $21 \%$ versus $63 \%$ in GO-treated cells while in ammonia-treated Colon 26 cells adhesion was $22.5 \%$ versus $42.6 \%$ in GO-treated Colon 26 cells. A greater reduction in the inhibitory concentration, $\mathrm{IC}_{50}$, of haGO- $\mathrm{NH}_{2}$ was also found, suggesting that amination by hydroxylamine is more effective than amination by ammonia. It should be kept in mind however the different type of the studied cells as well as the different tests used for calculating the $\%$ of cell adhesion on which the calculation of IC50 is based. The case based on Colon 26 cells is based on counting the number of attached cells by an automated cell counter (Countess, Invitrogen), while for HepG2 cells, the assay of WST-1.

Table 1. Comparison between different types of GO and aminated GO NPs studied in this study and in Krasteva et al., 2019 [20].

\begin{tabular}{|c|c|c|c|c|c|c|}
\hline Sample & Mean Size & $\mathrm{ZP}(\mathrm{mV}) \pm \mathrm{SE}$ & Polarity & $\begin{array}{l}\text { N1s } \\
\text { TOT. } \\
(\%)\end{array}$ & $\begin{array}{c}\mathrm{IC}_{50} \\
\text { HepG2 Cells }\end{array}$ & $\begin{array}{c}\mathrm{IC}_{50} \text { Colon } 26 \\
\text { Cells }\end{array}$ \\
\hline $\begin{array}{c}\frac{\mathrm{GO}}{\text { (ref. [20]) }} \\
\text { (this study) }\end{array}$ & $\begin{array}{l}250 \pm 68 \mathrm{~nm} \\
1.5 \pm 0.7 \mu \mathrm{m} \\
515 \pm 50 \mathrm{~nm} \\
3.6 \pm 0.5 \mu \mathrm{m}\end{array}$ & $\begin{array}{l}-24.5 \pm 0.4 \mathrm{mV} \\
-33.7 \pm 0.4 \mathrm{mV}\end{array}$ & negative & 0.99 & $62.97 \pm 10 \mu \mathrm{g} / \mathrm{mL}$ & $1.71 \pm 0.2 \mu \mathrm{g} / \mathrm{mL}$ \\
\hline$\frac{\mathrm{GO}-\mathrm{NH}_{2}}{\text { (ref. [20]) }}$ & $560 \pm 300 \mathrm{~nm}$ & $38.5 \pm 2.8 \mathrm{mV}$ & positive & 3.47 & & $1.26 \pm 0.1 \mu \mathrm{g} / \mathrm{mL}$ \\
\hline $\begin{array}{c}\text { haGO-NH} \mathrm{NH}_{2} \\
\text { hydroxylamine } \\
\text { modified (this study) }\end{array}$ & $594 \pm 270 \mathrm{~nm}$ & $-12.28 \pm 0.6 \mathrm{mV}$ & negative & 1.86 & $\begin{array}{c}3.4 \pm 0.7 \\
\mu \mathrm{g} / \mathrm{mL}\end{array}$ & \\
\hline
\end{tabular}

Biological activities of the newly synthesized aminated GO NPs were first assessed by evaluating HepG2 morphology and viability by means of Neutral Red staining and WST-1 assay. Generally, cell morphology together with cell viability are essential signs of the physiological status of the cells as both are important indicators for cytotoxicity. In our study, we found that the rate of survival of HepG2 cells, treated with pristine and aminated GO NPs, decreased with the increase in the concentrations of both types of nanomaterials, and dropped down to $80 \%$ after treatment with the highest concentration used, i.e., $50 \mu \mathrm{g} / \mathrm{mL}$, especially in the case with haGO-NH${ }_{2}$. This suggests high cellular toxicity, especially of the aminated GO NPs. The morphological observations under the 
light microscope did not disclose any significant differences in cell morphology. This is in contrast to other studies, including ours [20,38], that report pronounced morphological alterations, and the appearance of apoptotic-like morphology when $\mathrm{GO}$ and $\mathrm{GO}-\mathrm{NH}_{2}$ were used to treat macrophages and colorectal carcinoma cells. The difference in the results could be related to the different types of cells used in the experiments, and further to the different protocols for modification of the graphene oxide nanomaterials. Further, we measured LDH leakage in the cell culture medium and found an increased amount of LDH after exposure of HepG2 cells, only to haGO-NH $\mathrm{N}_{2} \mathrm{NPs}$, thus, suggesting damage in plasma membrane structural integrity. $\mathrm{LDH}$ is a relatively stable intracellular enzyme which can leak out only when the cell membrane is broken. Our results suggest that haGO- $\mathrm{NH}_{2}$ penetrates through the plasma membrane and probably disrupts the phospholipid bilayer unlike GO NPs. The last could be due to the fact that pristine GO NPs are larger in size, which possibly hinders penetration through the cell membrane. The results are in agreement with Chang et al. [11] who have measured a lower LDH leakage in A459 cells, treated with GO nanoparticles, with concentrations $50 \mu \mathrm{g} / \mathrm{mL}$ and above, compared to the control. A study by Sasidharan et al. compared carboxyl-functionalized graphene with pristine graphene, and found that no LDH leakage was observed at concentrations as high as $300 \mu \mathrm{g} / \mathrm{mL}$ in Vero cells [39]. Moreover, Zhang et al. [40] observed that graphene aggregates were attached to the surface of rat PC12 cells and caused an increase in LDH leakage only at the highest exposure concentration $(100 \mu \mathrm{g} / \mathrm{mL})$. On the contrary, Liao et al. demonstrated that both, pristine graphene and GO sheets were able to disrupt the plasma membrane of erythrocytes [41]. The discrepancy in the results might be explained with the different types of the cells used, different types of GO, as well as the different experimental design. It should be considered also the different mechanism of toxicity induced by NPs, and that LDH release is a marker of necrotic cell death [42,43]. Therefore, if the GO NPs induced apoptotic cell death without cell membrane damage, then LDH is not released in cell culture medium, and thus, cannot be measured.

Little is known about the mechanisms by which aminated graphene oxide nanoparticles induce toxicity. Some authors hypothesize that induction of cellular oxidative stress is considered as one of the mechanisms underlying nanomaterial toxicity in general. Commonly, oxidative stress results from the imbalance between oxidative and antioxidative defense systems of cells and tissues, and a result of overproduction of oxidative-free radicals and ROS. An outcome of excessive levels of ROS is the modification of the structure and function of cellular proteins and lipids, leading to cellular dysfunction, including impaired energy metabolism, altered cell signaling and cell cycle control, impaired cell transport mechanisms and overall dysfunctional biological activity, immune activation and inflammation [44-46]. Therefore, we measured the generation of ROS by studying the mechanisms of detected hepatotoxicity-induced by GO NPs. In our study, GO and haGO- $\mathrm{NH}_{2}$ nanoparticles were observed to induce generation of intracellular ROS in a concentration-dependent manner. In addition, $\mathrm{GO}$ and haGO- $\mathrm{NH}_{2}$ ROS production seemed to follow different trends. For GO, maximum ROS levels were reached after exposure to $50 \mu \mathrm{g} / \mathrm{mL}$ after $24 \mathrm{~h}$ of exposure of the cells to the nanoparticles. In cells treated with lower GO concentrations (between 4 and $25 \mu \mathrm{g} / \mathrm{mL}$ ), intracellular ROS levels were kept even lower than the control and eventually reached levels comparable to those measured for the control (especially at a concentration of $25 \mu \mathrm{g} / \mathrm{mL}$ ). On the contrary, $24 \mathrm{~h}$ of exposure to the increasing concentrations of haGO- $\mathrm{NH}_{2}(4-25 \mu \mathrm{g} / \mathrm{mL})$ resulted in significant increment in ROS levels while at the highest concentration of $50 \mu \mathrm{g} / \mathrm{mL}$, the detected ROS levels declined. Regarding the oxidant-generating potential of haGO- $\mathrm{NH}_{2}$, the obtained results are consistent with our previous observations for colorectal cancer cells where a bell-shaped curve of ROS production was shown for both types of GO (pristine and aminated) [20]. A possible explanation could be that GO particles have high adsorption potential, which may cause quenching of the signal by depleting the fluorophore, and thus, producing false signals. This very possibly could result in reduced ROS production at the highest concentrations of GO and GO-NH $\mathrm{N}_{2}$. Our results in respect of ROS production, induced by pristine GO NPs in HepG2 cells, are in accordance with those reported by other authors like Yuan et al. [47] who did not detect any significant increase in the intracellular ROS levels in HepG2 cells, 
exposed to $1 \mu \mathrm{g} / \mathrm{mL}$ of single-layered GO. Based on the obtained results here, and those in our previous study on ROS production in colon cancer cells, we conclude that the effect of GO on ROS formation is rather cell-specific. These conclusions are also supported by literature data on the ability of GO to induce the generation of intracellular ROS in other cell lines. A549 cells exposed to $10 \mu \mathrm{g} / \mathrm{mL}$ GO for $24 \mathrm{~h}$, in comparable ROS levels to those determined in this study [48]. In human skin fibroblasts, however, no significant increase with respect to the control could be detected after $24 \mathrm{~h}$ of exposure to concentrations as high as $25 \mu \mathrm{g} / \mathrm{mL}$ [49]. The discrepancy between the results obtained in this study and those stated above (including ours) might be due to differences in the lateral size of the nanoparticles tested $(>1 \mu \mathrm{m})$, the suspension protocol (serum-free medium), the assay protocol (loading of the cells with the dye DCFH-DA was carried out prior to treatment), not only due to the sensitivity of the used cell lines. To the best of our knowledge, no data on the oxidant-generating ability of haGO-NH${ }_{2}$ have been reported in the scientific literature. The fact that GO and haGO- $\mathrm{NH}_{2}$-induced ROS generation displayed different kinetics suggests that the underlying ROS generating mechanisms are distinct. The exact mechanism(s) by which a nanomaterial exerts oxidative stress is relatively difficult to be identified, and still remains to be elucidated for most nanomaterials, including graphene and its derivates. An integrative consideration of the results obtained by different assays can assist in obtaining the first indication on the possible mechanisms involved. In general, there are two possible mechanisms for ROS induction: Direct and indirect. Direct ROS generation typically involves processes that are independent of the presence of biological systems (namely acellular ROS generation), i.e., are solely a function of the nanomaterial's physico-chemical properties. Indirect ROS generation, on the contrary, typically involves cellular (i.e., biochemical) processes that were triggered by the nanomaterial beforehand [50].

Mitochondria perform essential functions in generating most of the cellular energy through the oxidative phosphorylation system and important metabolic intermediates in various pathways, such as amino acids, fatty acids and carbohydrates. It is known that mitochondria play compelling roles in carcinogenesis via altered energy metabolism, resistance to apoptosis, increased production of ROS and mtDNA (mitochondrial genome) changes [51-55]. ROS produced by nanoparticle-induced damage of the respiratory chain, likely by disturbing mitochondrial membrane permeability. When we investigated the nanomaterials' effect on cellular respiration in mitochondria, we found that the exposure to GO and haGO- $\mathrm{NH}_{2}$ nanoparticles resulted in the suppression of most of the phases of cellular respiration. Mitochondrial dysfunction is known to be associated with oxidative damage of mitochondrial macromolecules including mtDNA, lipids and proteins. [54]. Damage of mitochondrial functions can be provoked directly, i.e., by physical interaction of the nanomaterials with the mitochondrial membrane, or indirectly, e.g., by inducing damages through interactions with cell membrane protein receptors [56-59]. It is known that DNA is a critical target of ROS. A higher production of intracellular ROS may lead to the oxidative damage of DNA, including base and sugar lesions, DNA-protein crosslinks, single- and double-strand breaks, and the formation of alkali-labile sites [29]. In our previous studies, we have shown that ammonia-modified GO NPs have the potential to induce DNA damage and apoptosis in Colon 26 cancer cells. Hence, we have analysed here the newly synthesized haGO-NH $\mathrm{N}_{2} \mathrm{NPs}$ and their ability to destroy DNA in HepG2 cells. We found that hydroxylamine aminated GO induced only slight DNA damage, although caused ROS generation and mitochondrial dysfunction. This suggests that the mechanisms by which haGO- $\mathrm{NH}_{2} \mathrm{NPs}$ exert their biological activities are not centered on the stability and maintenance of the genome integrity, but rather in mitochondrial metabolism and oxidative damage. The latter is in contrast to the observed DNA damage in ammonia-modified GO in colon cancer cells. 


\section{Materials and Methods}

\subsection{Amination of Graphene Oxide Particles}

GO was purchased from Graphenea (C1576, San Sebastian, Spain) as a water suspension with a concentration of $4 \mathrm{mg} / \mathrm{mL}$. Amination was achieved by the addition of $2 \mathrm{~mL}$ hydroxylamine $(50 \%$ solution, Merck, Darmstadt, Germany) to $20 \mathrm{~mL}$ GO solution and was kept under continuous stirring on magnetic stir for $5 \mathrm{~h}$ at $80{ }^{\circ} \mathrm{C}$. Unreacted materials were removed by three times washing with deionized water by centrifugation at $3000 \mathrm{rpm}$ for $30 \mathrm{~min}$. The supernatant was removed and deionized water was added to the sediment up to $20 \mathrm{~mL}$. The optical density of the resulting product was measured at $270 \mathrm{~nm}$ wavelength in order to get the desired concentrations of aminated GO NPs.

Immediately before cell experiments, particle stock suspensions were sonicated in an ultrasonic water bath (50 Hz, UM-2, Unitra-Unima, Olsztyn, Poland) for $1 \mathrm{~h}$. The desired final concentrations of NPs $(4,10,25$, and $50 \mu \mathrm{g} / \mathrm{mL}$, respectively) were achieved by adding certain volume of the nanoparticles from the stock solutions directly into the culture medium.

TEM (JEM-2100, JEOL, Tokyo, Japan) images were acquired at $200 \mathrm{kV}$ using Holey-carbon film on 300 mesh nickel grids. Prior to TEM imaging GO and GO- $\mathrm{NH}_{2}$ suspensions were sonicated for $60 \mathrm{~min}$.

Dynamic light scattering (DLS) for characterization of size and zeta potential of the nanoparticles in solution, was performed on a Zetatrac instrument (S3500; Microtrac, Largo, FL, USA). Samples were examined after dilution of nanoparticle to a stock solution of $100 \mathrm{mg} / \mathrm{mL}$ suspensions in DI water, and sonicated for $1 \mathrm{~h}$, then $1 \mathrm{~mL}$ was transferred to a Zetatrac instrument for DLS measurement.

\subsection{Cell Culture}

HepG2 cells were grown in MEM culture medium supplemented with $10 \%$ fetal bovine serum (FBS, Sigma-Aldrich, Germany) and an antibiotic-antimycotic solution (Sigma-Aldrich, Germany). The cells were grown in a humidified environment with $5 \% \mathrm{CO}_{2}$ and $95 \%$ atmosphere at $37^{\circ} \mathrm{C}$. For in vitro experiments, the pre-confluent cells were detached using a mixture of $0.05 \%$ trypsin and $0.02 \%$ EDTA (Sigma-Aldrich, Germany) and were seeded at a density of $2 \times 10^{4}$ cells/well in a 24-well plate or $1 \times 10^{5}$ cells/well in 6-well plates depending on the protocol. Cells were cultivated for $24 \mathrm{~h}$ before exposure to increasing concentrations of $\mathrm{GO}$ and $\mathrm{GO}-\mathrm{NH}_{2}$ nanoparticles. After adding the nanoparticles, the cells were incubated for another 24,48 or $72 \mathrm{~h}$ and after that were processed according to the protocol. Control cells were processed in the same way as tested samples, but in the absence of nanoparticles.

\subsection{Phase-Contrast Light and Fluorescent Microscopy}

Phase-contrast light and fluorescent microscopy observations were done in order to evaluate alterations in cell morphology after $24 \mathrm{~h}$ of exposure to both types of GO NPs and the integrity of the cell membrane, respectively. The phase-contrast micrographs were taken at magnifications of $25 \times$ with a Leitz microscope equipped with a digital camera after staining of cells with neutral red (Sigma-Aldrich, Germany), while fluorescent micrographs were taken at magnification 10×, with an inverted microscope Axiovert 25 (Carl Zeiss, Germany), equipped with a digital camera after staining of cells with $0.001 \%$ fluorescein diacetate (FDA), as previously described [20].

\subsection{WST-1 Assay}

WST-1 (Sigma-Aldrich Co., Germany) was used to evaluate cell viability after 24 h exposure to GO NPs. It is a sensitive colorimetric assay using a water-soluble tetrazolium salt WST-1 (2-(2-methoxy-4-nitrophenyl)-3-(4-nitrophenyl)-5-(2,4-disulfophenyl)-2H-tetrazolium, monosodium salt) to quantify the number of live cells by producing an orange formazan dye upon bio-reduction in the presence of an electron carrier. Briefly, the WST-1 solution was added directly to the cells in ratio 1:10. After $4 \mathrm{~h}$ of incubation at $37^{\circ} \mathrm{C}$, at dark, the amount of the formazan produced was measured by 
absorbance at $450 \mathrm{~nm}$. Cell viability is demonstrated as a graph with the measured optical density (OD) values, where values represent the MEAN \pm STDV of three repetitive experiments.

$\mathrm{IC}_{50}$ values were calculated by means of GraphPad Prism 7 (GraphPad Software, San Diego, CA, USA) based on the data obtained from WST-1 assay - for HepG2 cells and from the number of attached cell, calculated by an automated cell counter (Countess, Invitrogen, USA) for Colon26 cells

\subsection{LDH Assay}

Membrane integrity was assessed by measuring extracellular lactate dehydrogenase (LDH), using a commercially available kit (LDH cytotoxicity detection kit, Roche Diagnostic, IN, USA). Cytosolic $\mathrm{LDH}$ is released from the cells into the culture medium if the integrity of the cell membrane deteriorates in case of irreversible cell death. Briefly, HepG2 cells were seeded in 24-well plates at a density of $2 \times 10^{4}$ cells $/ \mathrm{mL}$ culture medium. After $24 \mathrm{~h}$ of seeding, the culture medium was replaced with fresh one and the tested NPs with increasing concentrations were added to the wells. The plates were then incubated for $24 \mathrm{~h}$ at $37^{\circ} \mathrm{C}$ under $100 \%$ humidity and $5 \% \mathrm{CO}_{2}$. Cell-free culture media was collected. LDH activity was measured at $490 \mathrm{~nm}$ by UV-Visible absorbance microplate reader. Background and negative controls were obtained by LDH measurement of assay medium, and untreated cell medium, respectively. Total cellular LDH activity (positive control) was measured in cell lysates obtained by treatment with TritonX-100 solution. The $\mathrm{OD}_{490 \mathrm{~nm}}$ of the cells permeabilized with Triton $\mathrm{X}-100$, was accepted as $100 \%$ of LDH release. The percentage of LDH release in the cells treated with nanoparticles was calculated as a percentage and presented in a graph. Three repetitions of the experiment have been done and values are MEAN \pm STDV.

\subsection{DCFA-DA Analysis}

The production of intracellular reactive oxygen species (ROS) was measured using 2,7-dichlorofluorescin diacetate (DCFH-DA, Sigma-Aldrich, Germany) as described before [20,49]. The DCFH-DA is a non-fluorescent compound, which passively enters the cell and reacts with ROS to form the highly fluorescent compound dichlorofluorescin (DCF). In brief, HepG2 cells $\left(3 \times 10^{4}\right)$ were seeded in 24-well plates and allowed for adherence. Following respective exposure, the cells were washed twice with PBS and incubated for $30 \mathrm{~min}$ in dark in FBS-free culture medium, containing DCFH-DA $(20 \mu \mathrm{M})$. Then, the DCFH-DA containing medium was removed, the control (untreated) and the treated cells were rinsed twice with PBS, and the fluorescence intensity of DCF was detected on a spectrofluorometer upon excitation at $485 \mathrm{~nm}$ and emission at $520 \mathrm{~nm}$. The results are presented as graph, where by the bars represent the MEAN values \pm STDV of three experiment repetitions.

\subsection{Single-Cell Gel Electrophoresis (SCGE)}

SCGE was performed as previously described [29]. Briefly, $1 \times 10^{3}$ cells were mixed with $0.7 \%$ (f.c.) of low-gelling agarose (Sigma-Aldrich, Germany) and were layered as microgels on microscopic slides. The slides were then lysed in $146 \mathrm{mM} \mathrm{NaCl}, 30 \mathrm{mM}$ EDTA, pH 7, $10 \mathrm{mM}$ Tris-HCl, pH-7 and $0.1 \% \mathrm{~N}$-lauroylsarcosine (NLS, Sigma-Aldrich, Germany) at $10^{\circ} \mathrm{C}$ for $20 \mathrm{~min}$ and were electrophoresed for $20 \mathrm{~min}$ at $0.46 \mathrm{~V} / \mathrm{cm}$. The results were visualized under a fluorescent microscope after staining of gels with SYBR green (Molecular probes, Invitrogen). The results were quantified by Comet Assay specialized software CometScore. HepG2 cells treated with $5 \mathrm{mM} \mathrm{H}_{2} \mathrm{O}_{2}$ (Sigma-Aldrich, Germany) for $30 \mathrm{~min}$ at $37^{\circ} \mathrm{C}$ were used as a positive control for genotoxicity. After treatment the cells were washed in 1xPBS buffer (2.68 mM KCl, $1.47 \mathrm{mM} \mathrm{KH}_{2} \mathrm{PO}_{4}, 1.37 \mathrm{mM} \mathrm{NaCl}, 8 \mathrm{mM} \mathrm{Na}_{2} \mathrm{HPO}_{4}$ ), $\mathrm{pH} 7$ and subjected to Comet Assay. Comet Assay data analysis was done by the software CometScore and results are presented as a graph on which the MEAN values of the parameter Comet length \pm STDV are given as bars. 


\subsection{Mitochondrial Stress Analysis}

The mitochondrial oxygen consumption rate (OCR) and the extracellular acidification rate (ECAR) were analyzed simultaneously using a standard mitochondrial stress test paradigm on the Seahorse Bioscience XFp analyzer (Agilent Technologies, CA, USA). The cells were assayed for OCR and ECAR measurements following the manufacturer's instructions. Briefly, before analysis, cells were washed with unbuffered assay media (Seahorse XF DMEM, pH-7.4) without phenol red supplemented with glucose $(10 \mathrm{mM})$, sodium pyruvate $(1 \mathrm{mM})$ and glutamine $(2 \mathrm{mM})$, and incubated for $1 \mathrm{~h}$ in a $\mathrm{CO}_{2}$-free incubator at $37^{\circ} \mathrm{C}$. After the initial measurement of basal OCR and ECAR, the inhibitors of mitochondrial activity were injected sequentially in the ports on the cartridges. First, the inhibitor of ATP synthase oligomycin $(1 \mu \mathrm{M})$ was added to determine both parts of basal respiration - one, that is used to drive the ATP production and the other - independent proton leakage across the inner mitochondrial membrane. Next, the uncoupler of mitochondrial oxidative phosphorylation carbonyl cyanide-4-(trifuoromethoxy) phenylhydrazone (FCCP, $0.125 \mu \mathrm{M})$ was added. It induces a collapse of the inner membrane gradient, driving the mitochondria to respire at their maximal rate. Finally, the complex III inhibitor, antimycin A $(1 \mu \mathrm{M})$ together with complex I inhibitor rotenone $(1 \mu \mathrm{M})$, an inhibitor of mitochondrial NADH dehydrogenase, were added to determine non-mitochondrial respiration. Basal respiration or acidification was calculated using the mean of the three OCR or ECAR measurements, before the first injection. ATP-production, proton leak, as well as maximal respiration were calculated as the mean of three OCR measurement cycles after oligomycin, or FCCP injection, respectively. Maximal acidification was calculated as the mean of three ECAR measurement cycles after oligomycin injection. The OCR data were corrected for non-mitochondrial oxygen consumption under rotenone and antimycin A [59]. Two repetitions of the Seahorse experiments were performed for data quantitation.

\subsection{Statistical Analysis}

Data in this article were statistically analyzed by the Microsoft Excel software in which bars represent the MEAN values of the calculated parameters \pm STDV. Additionally, Student's $t$-test, where the probability levels of 0.05 were considered as statistically significant. Additionally, linear regression models were calculated for WST-1experiments for evaluation of cytotoxicity of the tested NPs on HepG2 cells.

\section{Conclusions}

In the present study, we developed a simple, effective, cheap and time-saving protocol for amination of GO by hydroxylamine. Hydroxylamine-aminated GONPs (haGO- $\mathrm{NH}_{2}$ ) were characterized by XPS, TEM, and Zetasizer. The results demonstrated that amination of GO by hydroxylamine decreased the size and zeta potential, but increased the wrinkles of the GO sheets. The cytotoxic responses to the newly synthesized aminated GO and the underlying mechanisms were investigated in hepatocellular carcinoma HepG2 cells. We observed that exposure to haGO-NH $\mathrm{N}_{2}$ significant induced cytotoxicity (reduced cell viability in a dose-dependent manner and cell membrane damage) and oxidative stress (increased ROS production and mitochondrial dysfunction) in HepG2 cells. No significant alterations in cell morphology, nor substantial DNA damage, were detected, compared to pristine GO and the control group. In conclusion, ROS production and extracellular acidification rate in mitochondria of haGO-NH$H_{2}$ treated cells could be a potential mechanism for cytotoxicity of hydroxylamine modified GO nanomaterials. These findings provide toxicological and mechanistic information that could enrich knowledge on molecular mechanisms exerted by pristine and modified GO nanomaterials in different biological systems. Their potential use as anticancer drugs and as vector delivery systems in cancer cells remains to be further elucidated. 
Author Contributions: Conceptualization, N.K. and M.G.; methodology, N.K., M.G., B.V., M.D.-F., P.Z., and G.S.; statistics, K.S.; writing-original draft preparation, N.K., M.G.; writing, review and editing, N.K., M.G., G.M., D.W., and V.S.; project administration, N.K. funding acquisition, N.K. and M.G. All authors have read and agreed to the published version of the manuscript.

Funding: This research was funded by National Research Foundation - Bilateral project Bulgaria-China (Grant number DNTS/ 01/6/2016) and partially by the Bulgarian National Research Fund (grant numbers: KP06-N31/15 and DN11/15) and NATO Science for Peace and Security programme (grant number: NATO SPS MYP G5266).

Conflicts of Interest: The authors declare no conflict of interest. The funders had no role in the design of the study; in the collection, analyses, or interpretation of data; in the writing of the manuscript, or in the decision to publish the results.

\section{References}

1. Davis, M.E.; Chen, Z.G.; Shin, D.M. Nanoparticle therapeutics: An emerging treatment modality for cancer. Nat. Rev. Drug Discov. 2008, 7, 771-782. [CrossRef] [PubMed]

2. Goncalves, G.; Vila, M.; Portoles, M.T.; Vallet-Regi, M.; Gracio, J.; Marques, P.A. Nano-graphene oxide: A potential multifunctional platform for cancer therapy. Adv. Healthc. Mater. 2013, 2, 1072-1090. [CrossRef] [PubMed]

3. Tao, W.; Zhu, X.; Yu, X.; Zeng, X.; Xiao, Q.; Zhang, X.; Ji, X.; Wang, X.; Shi, J.; Zhang, H.; et al. Black phosphorus nanosheets as a robust delivery platform for cancer theranostics. Adv. Mater. 2017, 29. [CrossRef]

4. Wang, S.B.; Ma, Y.Y.; Chen, X.Y.; Zhao, Y.Y.; Mou, X.Z. Ceramide-Graphene Oxide Nanoparticles Enhance Cytotoxicity and Decrease HCC Xenograft Development: A Novel Approach for Targeted Cancer Therapy. Front Pharmacol. 2019, 10, 69. [CrossRef] [PubMed]

5. Zhu, X.; Ji, X.; Kong, N.; Chen, Y.; Mahmoudi, M.; Xu, X.; Ding, L.; Tao, W.; Cai, T.; Li, Y.; et al. Intracellular mechanistic understanding of $2 \mathrm{~d}$ mos2 nanosheets for antiexocytosis-enhanced synergistic cancer therapy. ACS Nano 2018, 12, 2922-2938. [CrossRef] [PubMed]

6. Priyadarsini, S.; Mohanty, S.; Mukherjee, S. Graphene and graphene oxide as nanomaterials for medicine and biology application. J. Nanostruct. Chem. 2018, 8, 123-137. [CrossRef]

7. Campbell, E.; Hasan, M.T.; Pho, C.; Callaghan, K.; Akkaraju, G.R.; Naumov, A.V. Graphene Oxide as a Multifunctional Platform for Intracellular Delivery, Imaging, and Cancer Sensing. Sci. Rep. 2019, 9, 416. [CrossRef]

8. Dave, S.H.; Gong, C.; Robertson, A.W.; Warner, J.H.; Grossman, J.C. Chemistry and Structure of Graphene Oxide via Direct Imaging. ACS Nano 2016, 10, 7515-7522. [CrossRef]

9. Wu, S.; Zhao, X.; Cui, Z.; Zhao, C.; Wang, Y.; Du, L.; Li, Y. Cytotoxicity of graphene oxide and graphene oxide loaded with doxorubicin on human multiple myeloma cells. Int. J. Nanomed. 2014, 9, 1413-1421. [CrossRef]

10. Sohail, M.; Saleem, M.; Ullah, S.; Saeed, N.; Afridi, A.; Khan, M.; Arif, M. Modified and improved Hummer's synthesis of graphene oxide for capacitors applications. Mod. Electron. Mater. 2017, 3, 110-116. [CrossRef]

11. Chang, Y.; Yang, S.-T.; Liu, J.-H.; Dong, E.; Wang, Y.; Cao, A.; Liu, Y.; Wang, H. In vitro toxicity evaluation of graphene oxide on A549 cells. Toxicol. Lett. 2011, 200, 201-210. [CrossRef] [PubMed]

12. Kutwin, M.; Sawosz, E.; Jaworski, S.; Wierzbicki, M.; Strojny, B.; Grodzik, M.; Sosnowska, M.-E.; Trzaskowski, M.; Chwalibog, A. Nanocomplexes of Graphene Oxide and Platinum Nanoparticles against Colorectal Cancer Colo205, HT-29, HTC-116, SW480, Liver Cancer HepG2, Human Breast Cancer MCF-7, and Adenocarcinoma LNCaP and Human Cervical Hela B Cell Lines. Materials 2019, 12, 909. [CrossRef]

13. Loutfy, S.A.; Salaheldin, T.A.; Ramadan, M.A.; Farroh, K.Y.; Abdallah, Z.F.; Youssef, T. Synthesis, characterization and cytotoxic evaluation of graphene oxide nanosheets: In vitro liver cancer model. Asian Pac. J. Cancer Prev. 2017, 18, 955-961. [CrossRef]

14. Pelin, M.; Fusco, L.; León, V.; Martín, C.; Criado, A.; Sosa, S.; Vázquez, E.; Tubaro, A.; Prato, M. Differential cytotoxic effects of graphene and graphene oxide on skin keratinocytes. Sci. Rep. 2017, 7, 40572. [CrossRef]

15. Lammel, T.; Boisseaux, P.; Fernández-Cruz, M.L.; Navas, J.M. Internalization and cytotoxicity of graphene oxide and carboxyl graphene nanoplatelets in the human hepatocellular carcinoma cell line HepG2. Part. FibreToxicol. 2013, 10, 27. [CrossRef]

16. Hu, W.; Peng, C.; Lv, M.; Li, X.; Zhang, Y.; Chen, N.; Fan, C.; Huang, Q. Protein corona-mediated mitigation of cytotoxicity of graphene oxide. ACS Nano 2011, 5, 3693-3700. [CrossRef] 
17. Ding, Z.; Zhang, Z.; Ma, H.; Chen, Y. In vitro hemocompatibility and toxic mechanism of graphene oxide on human peripheral blood T lymphocytes and serum albumin. ACS Appl. Mater. Interfaces 2014, 6, 19797-19807. [CrossRef]

18. Wen, H.; Dong, C.; Dong, H.; Shen, A.; Xia, W.; Cai, X.; Song, Y.; Li, X.; Li, Y.; Shi, D. Engineered redox-responsive PEG detachment mechanism in PEGylated nano-graphene oxide for intracellular drug delivery. Small 2012, 12, 760-769. [CrossRef]

19. Saifullah, B.; Buskaran, K.; Shaikh, R.B.; Barahuie, F.; Fakurazi, S.; MohdMoklas, M.A.; Hussein, M.Z. Graphene Oxide-PEG-Protocatechuic Acid Nanocomposite Formulation with Improved Anticancer Properties. Nanomaterials 2018, 8, 820. [CrossRef]

20. Krasteva, N.; Keremidarska-Markova, M.; Hristova-Panusheva, K.; Andreeva, T.; Speranza, G.; Wang, D.; Draganova-Filipova, M.; Miloshev, G.; Georgieva, M. Aminated Graphene Oxide as a Potential New Therapy for Colorectal Cancer. Oxid Med. Cell Longev. 2019, 3738980. [CrossRef]

21. Keremidarska-Markova, M.; Hristova-Panusheva, K.; Andreeva, T.; Speranza, G.; Wang, D.; Krasteva, N. Cytotoxicity evaluation of ammonia-modified graphene oxide particles in lung cancer cells and embryonic stem cells. Adv. Condens. Matter Physics. 2018, 11, 9571828. [CrossRef]

22. Bouattour, M.; Raymond, E.; Qin, S.; Cheng, A.-L.; Stammberger, U.; Locatelli, G.; Faivre, S. Recent developments of c-Met as a therapeutic target in hepatocellular carcinoma. Hepatology 2018, 67, 1132-1149. [CrossRef] [PubMed]

23. Bray, F.; Ferlay, J.; Soerjomataram, I.; Siegel, R.L.; Torre, L.A.; Jemal, A. “Global cancer statistics 2018: GLOBOCAN estimates of incidence and mortality worldwide for 36 cancers in 185 countries. Cancer J. Clin. 2018, 68, 394-424. [CrossRef] [PubMed]

24. Rawla, P.; Sunkara, T.; Muralidharan, P.; Raj, J.P. Update in global trends anvol. daetiology of hepatocellular carcinoma. Contemp Oncol (Pozn). 2018, 22, 141-150. [CrossRef] [PubMed]

25. ErfaniKarimzadehToosi, A. ERRATUM for the paper Erfani, A. Liver Fibrosis: Causes and Methods of Assessment. A Review. Rom. J. Intern. Med. 2015, 53, 304-314. [CrossRef]

26. Liu, C.Y.; Chen, K.F.; Chen, P.J. Treatment of Liver Cancer. Cold Spring Harb. Perspect Med. 2015, 5, a021535. [CrossRef]

27. Finn, R.S. Development of molecularly targeted therapies in hepatocellular carcinoma: Where do we go now? Clin. Cancer Res. 2010, 16, 390-397. [CrossRef]

28. Llovet, J.M.; Ricci, S.; Mazzaferro, V.; Hilgard, P.; Gane, E.; Blanc, J.F.; de Oliveira, A.C.; Santoro, A.; Raoul, J.L.; Forner, A. Sorafenib in advanced hepatocellular carcinoma. N. Engl. J. Med. 2008, 359, 378-390. [CrossRef]

29. Keating, G.M.; Santoro, A. Sorafenib: A review of its use in advanced hepatocellular carcinoma. Drugs 2009, 69, 223-240. [CrossRef]

30. Ostolska, I.; Wiśniewska, M. Application of the zeta potential measurements to explanation of colloidal $\mathrm{Cr}_{2} \mathrm{O}_{3}$ stability mechanism in the presence of the ionic polyamino acids. Colloid Polym Sci. 2014, 292, 2453-2464. [CrossRef]

31. Roberto, L.E.; Ribeiro, C. (Eds.) Basic Principles: Thermodynamics and Colloidal Chemistry. In Crystallization and Growth of Colloidal Nanocrystals; Springer: Berlin/Heidelberg, Germany, 2011; Volume 2.

32. Gurunathan, S.; Qasim, M.; Park, C.H.; Iqbal, M.A.; Yoo, H.; Hwang, J.H.; Uhm, S.J.; Song, H.; Seo, H.G.; Choi, Y.; et al. Cytotoxicity and Transcriptomic Analyses of Biogenic Palladium Nanoparticles in Human Ovarian Cancer Cells (SKOV3). Nanomaterials 2019, 9, 787. [CrossRef] [PubMed]

33. Tee, J.K.; Ong, C.N.; Bay, B.H.; Ho, H.K.; Leong, D.T. Oxidative stress by inorganic nanoparticles. Wiley Interdiscip. Rev. Nanomed. Nanobiotechnol. 2016, 8, 414-438. [CrossRef] [PubMed]

34. Shen, Y.; Wu, L.; Qin, N.; Xia, Y.; Zhou, Z.; Zhang, X.; Wu, X. Carbon black suppresses the osteogenesis of mesenchymal stem cells: The role of mitochondria. Part FibreToxicol. 2018, 15, 16. [CrossRef] [PubMed]

35. Olive, P.L.; Wlodek, D.; Durand, R.E.; Banáth, J.P. Factors influencing DNA migration from individual cells subjected to gel electrophoresis. Exp. Cell Res. 1992, 198, 259-267. [CrossRef]

36. Fairbairn, D.W.; Olive, P.L.; O’Neill, K.L. The comet assay: A comprehensive review. Mutat. Res. 1995, 339, 37-59. [CrossRef] 
37. Olive, P.L.; Banath, J.P. The comet assay: A method to measure DNA damage in individual cells. Nat. Protoc. 2006, 1, 23-29. [CrossRef] [PubMed]

38. Xu, M.; Zhu, J.; Wang, F.; Xiong, Y.; Wu, Y.; Wang, Q.; Weng, J.; Zhang, Z.; Chen, W.; Liu, S. Improved In Vitro and In Vivo Biocompatibility of Graphene Oxide through Surface Modification: Poly (Acrylic Acid)-Functionalization is Superior to PEGylation. ACS Nano 2016, 10, 3267-3281. [CrossRef]

39. Sasidharan, A.; Panchakarla, L.S.; Chandran, P.; Menon, D.; Nair, S.; Rao, C.N.R.; Koyakutty, M. Differential nano-bio interactions and toxicity effects of pristine versus functionalized graphene. Nanoscale 2011, 3, 2461-2464. [CrossRef]

40. Zhang, Y.; Ali, S.F.; Dervishi, E.; Xu, Y.; Li, Z.; Casciano, D.; Biris, A.S. Cytotoxicity effects of graphene and single-wall carbon nanotubes in neural phaeochromocytoma-derived PC12 cells. ACS Nano 2010, 4, 3181-3186. [CrossRef]

41. Liao, K.H.; Lin, Y.S.; Macosko, C.W.; Haynes, C.L. Cytotoxicity of graphene oxide and graphene in human erythrocytes and skin fibroblasts. ACS Appl. Mater. Interfaces 2011, 3, 2607-2615. [CrossRef]

42. Chan, F.K.-M.; Moriwaki, K.; De Rosa, M.J. Detection of Necrosis by Release of Lactate Dehydrogenase (LDH) Activity. Methods Mol. Biol. 2013, 979, 65-70. [CrossRef] [PubMed]

43. Helm, K.; Beyreis, M.; Mayr, C.; Ritter, M.; Jakab, M.; Kiesslich, T.; Plaetzer, K. In Vitro Cell Death Discrimination and Screening Method by Simple and Cost-Effective Viability Analysis. Cell Physiol. Biochem. 2017, 41, 1011-1019. [CrossRef] [PubMed]

44. Akhavan, O.; Ghaderi, E.; Akhavan, A. Size-dependent genotoxicity of graphene nanoplatelets in human stem cells. Biomaterials 2012, 33, 8017-8025. [CrossRef] [PubMed]

45. Jaworski, S.; Sawosz, E.; Kutwin, M.; Wierzbicki, M.; Hinzmann, M.; Grodzik, M.; Winnicka, A.; Lipińska, L.; Wlodyga, K.; Chwalibog, A. In vitro and in vivo effects of graphene oxide and reduced graphene oxide on glioblastoma. Int. J. Nanomed. 2015, 10, 1585-1596. [CrossRef]

46. Newsholme, P.; Cruzat, V.F.; Keane, K.N.; Carlessi, R.; de Bittencourt, P.I. Molecular mechanisms of ROS production and oxidative stress in diabetes. Biochem. J. 2016, 473, 4527-4550. [CrossRef]

47. Yuan, J.; Gao, H.; Sui, J.; Duan, H.; Chen, W.N.; Ching, C.B. Cytotoxicity evaluation of oxidized single-walled carbon nanotubes and graphene oxide on human hepatoma HepG2 cells: aniTRAQ-coupled 2DLC-MS/MS proteome analysis. Toxicol. Sci. 2012, 126, 149-161. [CrossRef]

48. Ahamed, M.; Akhtar, M.J.; Majeed Khan, M.A.; Alaizeri, Z.A.M.; Alhadlaq, H.A. Evaluation of the Cytotoxicity and Oxidative Stress Response of $\mathrm{CeO}_{2}-\mathrm{RGO}$ Nanocomposites in Human Lung Epithelial A549 Cells. Nanomaterials 2019, 9, 1709. [CrossRef]

49. Liao, C.; Li, Y.; Tjong, S.C. Graphene Nanomaterials: Synthesis, Biocompatibility, and Cytotoxicity. Int. J. Mol. Sci. 2018, 19, 3564. [CrossRef]

50. Manke, A.; Wang, L.; Rojanasakul, Y. Mechanisms of nanoparticle-induced oxidative stress and toxicity. Biomed. Res. Int. 2013, 2013, 942916. [CrossRef]

51. Dayem, A.A.; Hossain, M.K.; Lee, S.; Kim, K.; Saha, S.K.; Yang, G.-M.; Choi, H.Y.; Cho, S.-G. The Role of Reactive Oxygen Species (ROS) in the Biological Activities of Metallic Nanoparticles. Int. J. Mol. Sci. 2017, 18, 120. [CrossRef]

52. Petros, J.A.; Baumann, A.K.; Ruiz-Pesini, E.; Amin, M.B.; Sun, C.Q.; Hall, J.; Lim, S.; Issa, M.M.; Flanders, W.D.; Hosseini, S.H.; et al. Mt DNA mutations increase tumorogenisity in prostate cancer. Proc. Natl. Acad. Sci. USA 2005, 102, 719-724. [CrossRef] [PubMed]

53. Czarnecka, A.M.; Gammazza, A.M.; Di Felice, V. Cancer as a "Mitochondriopathy". J. Cancer 2007, 3, 71-79.

54. Plak, K.; Czarnecka, A.M.; Krawczyk, T. Breast cancer as a mitochondria disorder(Review). Oncol. Rep. 2009, 21, 845-851. [PubMed]

55. Mates, J.M.; Segura, J.A.; Campos-Sandoval, J.A. Glutamine homeostasis andmitochondrial dynamics. Int. J. Biochem. Cell Biol. 2009, 41, 2051-2061. [CrossRef] [PubMed]

56. Cairns, R.A.; Hariss, I.S.; Mak, T.W. Regulation of cancer cell metabolism. Nat. Rev. Cancer 2011, 11, 85-95. [CrossRef] [PubMed]

57. Czarnecka, A.M.; Golik, P.; Bartnik, E. Mitochondrial DNA mutations in human neoplasia. J. Appl. Genet. 2006, 47, 67-78. [CrossRef] [PubMed] 
58. Księżakowska-Łakoma, K.; Żyła, M.; Wilczyński, J.R. Mitochondrial dysfunction in cancer. Prz. Menopauzalny 2014, 13, 136-144. [CrossRef]

59. Ducray, A.; Felser, A.; Zielinski, J.; Bittner, A.; Bürgi, J.V.; Nuoffer, J.-M.; Frenz, M.; Mevissen, M. Effects of silica nanoparticle exposure on mitochondrial function during neuronal differentiation. J. Nanobiotechnol. 2017, 15, 49. [CrossRef] [PubMed] 